\title{
Physiological comparisons of crested wheatgrass and western wheatgrass to water
}

\author{
A. B. FRANK
}

Author is with the USDA Agricultural Research Service, Northern Great Plains Research Laboratory, P. O. Box 459, Mandan, N.D.58554.

\begin{abstract}
Knowledge about mechanisms of water stress tolerance, growth, and development of forages are important in development of management practices and in germplasm improvement. Plants of crested wheatgrass [Agropyron desertorum (Fischer ex Link) Schultes] and western wheatgrass [Pascopyrum smithii (Rydb. ) Gould] were field grown at 3 soil water levels $(50,100$, and $150 \%$ of average rainfall) and $2 \mathrm{~N}$ levels $(10$ and $110 \mathrm{~kg} \mathrm{~N} \mathrm{ha-1)}$ and sampled to determine proline, water soluble carbohydrate, and abscisic acid concentration from about the 4-leaf through heading stages of development. Proline concentration increased in both species as water stress increased. Proline decreased in crested wheatgrass but increased in western wheatgrass as plant development advanced. Abscisic acid concentrations increased in both species as water stress increased. Western wheatgrass contained about 1.7 times higher abscisic acid concentration than crested wheatgrass. Carbohydrate concentrations increased with water stress and were higher in crested than western wheatgrass. Increasing proline and abscisic acid concentrations in western wheatgrass and the decreasing concentrations in crested wheatgrass at later stages of development suggest that the stress response mechanisms that enhance proline and abscisic acid may be more operative in western than crested wheatgrass. These results suggesting that western wheatgrass is more tolerant of water stress under field conditions than crested wheatgrass should be useful in developing sustainable management practices. Also, proline concentration changes with plant development suggesting that germplasm sampling should be performed over time.
\end{abstract}

Key Words: water stress, plant development, canopy temperature, Agropyron desertorum, Pascopyrum smithii, proline, abscisic acid, carbohydrates

Crested wheatgrass in seeded pastures and western wheatgrass in native rangeland are important cool-season grasses for the northern Great Plains. Crested wheatgrass generally produces an abundant supply of early spring forage, but little summer forage due to early leaf senescence. Western wheatgrass produces less forage in early

Manuscript accepted 23 Jan. 1994. spring, but more during the summer period. The rapid early growth in crested wheatgrass followed by rapid leaf senescence as water and temperature stresses increase suggests a drought escaping rather than drought tolerance mechanism. Tadmore et al. (1970) suggested that drought escaping strategies and not tolerance may be the mechanism by which grasses can tolerate periods of extreme drought. Haferkamp et al. (1992) reported that after a severe summer drought only $16 \%$ of crested wheatgrass plants were viable in September. Responses suggesting that crested wheatgrass is less drought tolerant include lower leaf water potentials during periods of mild water stress (Bittman and Simpson 1989; Frank 1983) and greater water loss for a given change in leaf turgor potential when compared to other cool-season grasses (Bittman and Simpson 1989).

Metabolic changes that occur in water stressed plants cause changes in cellular chemical constituents. The amino acid proline often accumulates in plants exposed to water stress (Aspinall and Paleg 1981). Inorganic ions, particularly potassium, and to a lesser extent soluble sugars, may accumulate as well and like proline may contribute to osmotic adjustment in plants (Ford and Wilson 1981). Bokhari and Trent (1985) reported that droughted plants of tall fescue (Festuca arundinacea Schreb.) and western wheatgrass contained higher concentrations of proline than nonstressed plants. In growth chamber studies, water stressed western wheatgrass contained about 2.5 times more proline than stressed tall fescue.

Researchers differ in their interpretation of the accumulation of proline during drought. Stewart and Hanson (1980) suggest that proline accumulation in response to drought in barley (Hordeum vulgare L.) is not an adaptive metabolic response. Barnett and Naylor (1966) and Sivaramakrishnan et al. (1988) proposed that proline accumulation allows storage of nitrogen and carbon for use as an energy source when drought is relieved with no direct effect on drought resistance. The usefulness of proline accumulation as an index for germplasm evaluation for drought tolerance is not clcar.

Abscisic acid also accumulates in leaves and roots of water stressed plants (Dingkuhn et al. 1991). Abscisic acid was shown to induce proline accumulation in barley leaves (Rajagopal and Anderson 1978, Pesci 1987). Varietal differences for abscisic acid accumulation during stress development have been reported for maize (Zea mays L.) (Ilahi and Dorffling 1982) spring wheat (Triticum aestivum L.) (Quarrie 1980) and rice (Oryza sativa L.) (Dingkuhn et al. 1991).

Effects of water stress on carbohydrate concentration varies depending on species, degree of stress, and plant developmental stage (Trlica and Cook 1972). Stress caused by severe defoliation, such as grazing or clipping, generally reduces storage carbohydrates, (Buwai and Trlica 1977). Carbohydrates typically accumulate in tis- 
sues of water-stressed cool-season grasses because growth processes are curtailed before photosynthesis (Trlica and Cook 1972, Busso et al. 1990). This accumulation of total nonstructural carbohydrates probably facilitates rapid regrowth after water stress is relieved.

The objectives of this study were to compare crested and western wheatgrass for proline, abscisic acid, and carbohydrate concentration and to relate differences to water stress development in order to better understand physiological responses to drought in these important grasses.

\section{Methods and Materials}

'Rodan' western wheatgrass and 'Nordan' crested wheatgrass were seeded in a rain-out shelter on 22 Aug. 1983. The soil was a Parshall fine, sandy loam (Pachic Haploborolls). The rain-out shelter was designed to automatically cover the plot area during rainfall events. An overhead sprinkler system, located in the rain shelter, was used to supply water to the seeding to enhance plant establishment and to provide water after establishment. Plots were arranged in a split-plot design with 3 replicates. Main plots were 3 water treatments equivalent to 50,100 , and $150 \%$ of average long-term monthly precipitation for April through October. The average monthly precipitation for April, May, June, July, August, September, and October at Mandan is $39,55,85,61,43,38$, and $24 \mathrm{~mm}$, respectively. The appropriate quantity of water was applied equally, most often on Wednesday but occasionally on Thursday or Friday during each week, to achieve the monthly total. The rain-out shelter was not operated from 1 November to 1 April allowing the plots to be exposed to natural winter weather. Subplots were nitrogen fertilizer $\left(\mathrm{NH}_{4} \mathrm{NO}_{3}\right)$ broadcast at 10 and $110 \mathrm{~kg} \mathrm{~N} \mathrm{ha}^{-1}$ about 1 April each year.

Plant development stage was determined by the Haun scale (Haun 1973) 3 times weekly each year from beginning of development in the spring through head extension. The Haun scale is a numerical expression of development based on the number of leaves produced on the main stem and plant morphological units through heading stage.

Plant leaf tissue was sampled during morning hours by clipping at 2-cm stubble height on 5 dates during 1984, 1985, and 1986 between Haun development stage 4.1 to 10.0 for crested wheatgrass and Haun development stage 3.5 to 11.0 for western wheatgrass. Plant leaf tissue for determination of proline and water soluble carbohydrate concentrations was stored on ice after clipping and then dried at $70^{\circ} \mathrm{C}$ and ground to pass a $0.64 \mathrm{~mm}$ screen.

Canopy temperature was measured weekly during the growing season using a hand-held infrared thermometer with a $3^{\circ}$ field of view. The thermometer was held at about a $45^{\circ}$ angle to the canopy with the sun to the operator's back while taking measurements. Soil water potential (standardized to $25^{\circ} \mathrm{C}$ ) was measured weekly each year at 45-cm depth using thermocouple psychrometers.

Proline concentration was determined according to the procedures of Bates (1973). A 250-mg dried tissue sample was extracted with 10 $\mathrm{ml}$ of $3 \%$ aqueous sulfosalicylic acid and filtered through Whatman' No. 2 filter paper. Two milliliters of filtrate were treated with $2 \mathrm{ml}$ of acid-ninhydrin, $2 \mathrm{ml}$ of glacial acidic acid and heated for 1 hour at $100^{\circ} \mathrm{C}$. The reaction was terminated in an ice bath. The mixture was extracted with $4 \mathrm{ml}$ of toluene, shaken thoroughly, and the chromophore containing toluene removed, warmed to room temperature and absorbance read at $520 \mathrm{~nm}$ using toluene as a blank.

The water, but not the $\mathrm{N}$ treatments were maintained for both species from 1986 through 1990 . In 1990, the top collared leaf, excluding the flag leaf, was sampled for abscisic acid on 8 dates that differed in Haun stage of development. Fresh leaf tissue was ground
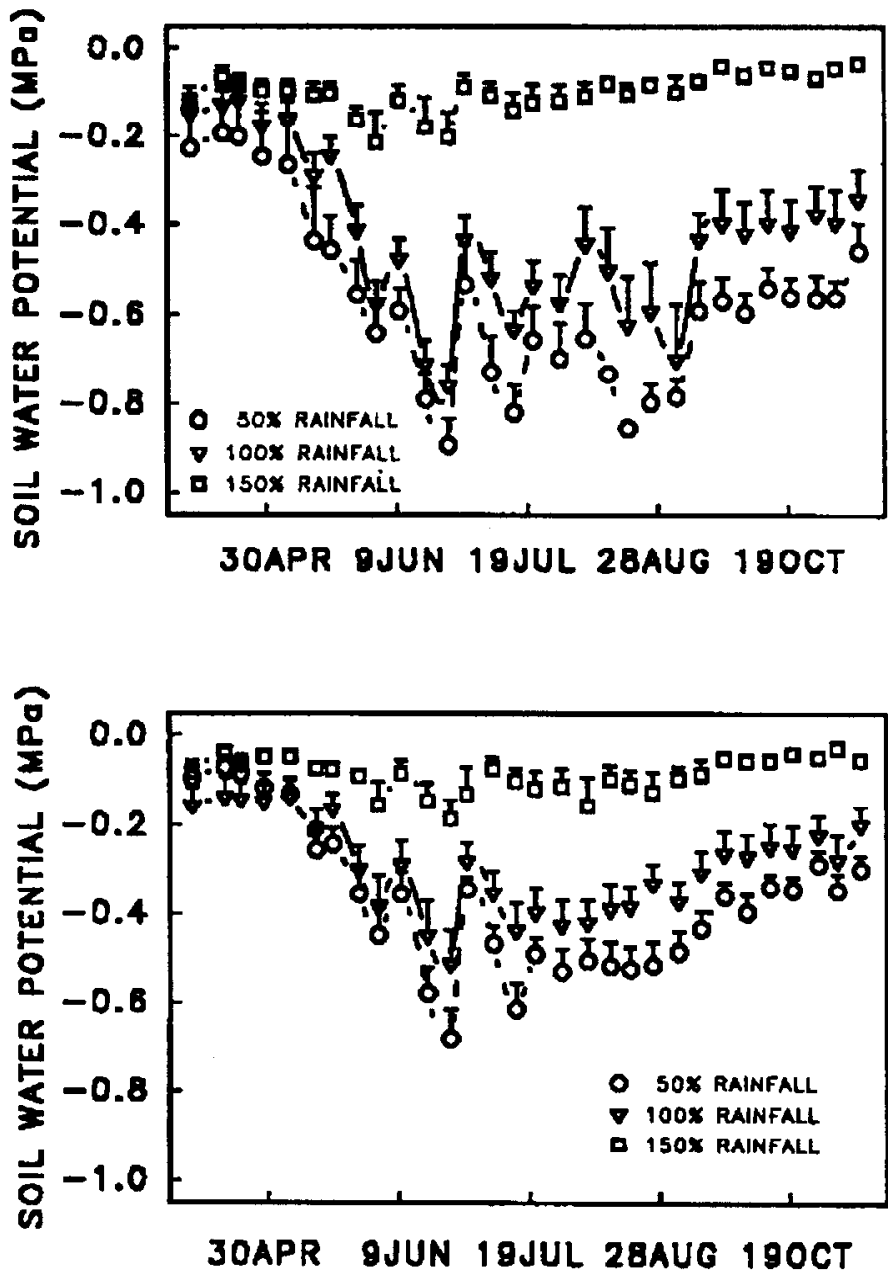

Fig. 1. Soil water potentials in 1986 at $45-\mathrm{cm}$ depth for crested wheatgrass (top) and western wheatgrass (bottom) at 3 water treatments. Vertical bars are standard errors of the mean.

in liquid nitrogen with a mortar and pestle. The powder was extracted with $25 \mathrm{mM}$ Tris- $\mathrm{HCl}$ and centrifuged at $3,000 \mathrm{~g}$ for $15 \mathrm{~min}$. The pellet was resuspended in extraction buffer and placed in the dark at 2$4^{\circ} \mathrm{C}$ for 24 hours after which it was centrifuged at $3,000 \mathrm{~g}$ for $15 \mathrm{~min}$. Leaf abscisic acid concentration was determined using Idetek's ${ }^{1}$ PHYTODETEK-ABA enzyme immunoassay which utilizes a monoclonal antibody to abscisic acid.

Water soluble carbohydrate concentration was determined on 250 mg dried leaf tissue samples after extraction with $35 \mathrm{ml}$ distilled water for $30 \mathrm{~min}$ at $25^{\circ} \mathrm{C}$ in a shaker bath (Jones and Nelson 1979). The extract was filtered through Whatman ${ }^{1}$ No. 40 paper, hydrolyzed with $0.1 \mathrm{~N} \mathrm{H}_{2} \mathrm{SO}_{4}$, and heated for $15 \mathrm{~min}$ in a boiling water bath. The extract was cooled to less than $30^{\circ} \mathrm{C}$ and neutralized with $\mathrm{NaOH}$. Reducing power of the hydrolyzed extract was measured by the Schaeffer-Somogyi copper-iodometric titration method as described by Smith (1969). Duplicate extractions were analyzed for each sample. Concentration of water soluble carbohydrates are presented as percent of dry weight.

The carbohydrate and proline concentration data from 1984, 1985,

\footnotetext{
Mention of trade name, proprietary product, or specific equipment does not constitute a guarantee or warranty of the product by the USDA-ARS and does not imply approval to the exclusion of other products that may be suitable.
} 
and 1986 for each species were analyzed separately as a split-splitplot design using SAS (SAS 1990) general linear models procedures. Water was the main plot, $\mathrm{N}$ the sub-plot, and Haun stage the sub-subplot. The abscisic acid, carbohydrate and proline concentration data for 1990 were analyzed as a split-plot where water was the main plot and Haun stage the sub-plot. Means were separated with the LSD $(P=0.05)$ test.

\section{Results}

\section{Soil Water Potential}

Differences among treatments for soil water potential were similar during all 3 years of the study, so for purposes of showing differences among rainfall treatments only measurements made in 1986 are presented (Fig. 1). Soil water potentials at the $150 \%$ water treatment were greater than $-0.2 \mathrm{MPa}$ at all dates for both species, whereas values for the 50 and $100 \%$ treatments varied from about -0.2 to $0.8 \mathrm{MPa}$ during the high water use period from mid-May through June. The 3-year season-long average soil water potential was -0.51 , -0.40 , and $-0.20 \mathrm{MPa}$ for crested wheatgrass and $-0.31,-0.26$, and $0.15 \mathrm{MPa}$ for western wheatgrass at the 50,100 , and $150 \%$ water treatments, respectively. The water treatments coincide with soil water potentials for both species and indicate increased water stress as amount of applied water decreased.
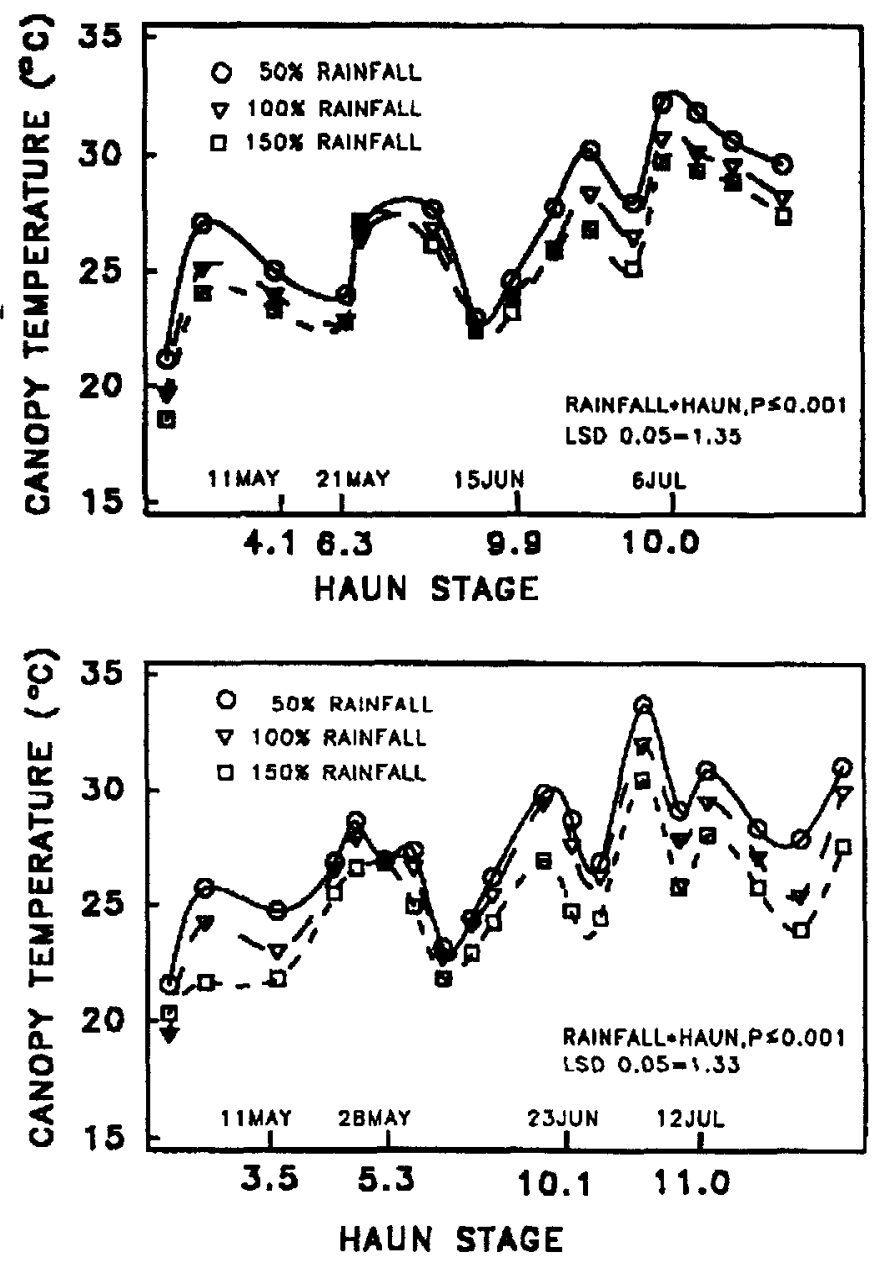

Fig. 2. Canopy temperature during development of crested wheatgrass (top) and western wheatgrass (bottom) grown at 50, 100, and 150\% rainfall.
Table 1. Canopy temperature for crested and western wheatgrass grown at 50,100 , or $150 \%$ of average growing season rainfall in 1990 .

\begin{tabular}{lcc}
\hline Rainfall & Crested Wheatgrass & Western Wheatgrass \\
\hline$-\%$ con & & \\
50 & 29.3 & 29.2 \\
100 & 26.7 & 27.0 \\
150 & 25.3 & 25.2 \\
LSD (0.05) Rainfall & 0.91 & 1.04 \\
\hline
\end{tabular}

\section{Canopy Temperatures}

Canopy temperatures for the 1984-1986 study were higher on most dates as applied water decreased from $150 \%$ to $50 \%$ (Fig. 2). Seasonlong canopy temperatures for each treatment were significantly different and averaged $27.7,26.4$, and $25.8^{\circ} \mathrm{C}$ for crested wheatgrass
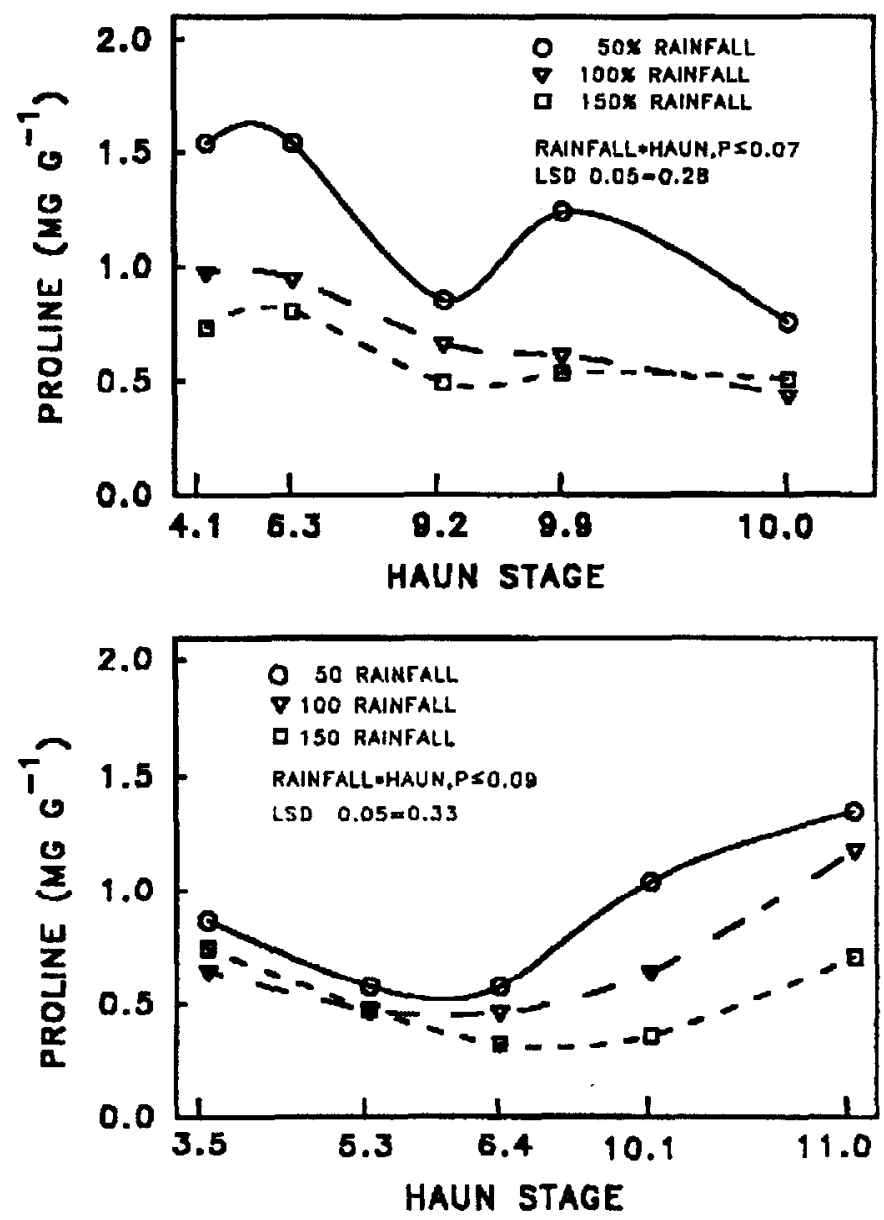

Fig. 3. Proline concentration during development of crested wheatgrass (top) and western wheatgrass (bottom) grown at 50, 100, and $150 \%$ rainfall. The $x$-axis is scaled linearly by day of year of Haun stage. The date that corresponded to each Haun stage for crested wheatgrass was 11 May, 21 May, 4 June, 15 June, and 6 July for Haun 4.1, 6.3, 9.2, 9.9, and 10.0, respectively, and for western wheatgrass the date was 11 May, 28 May, 4 June, 23 June, and 12 July for Haun 3.5, 5.3, 6.4, 10.1, and 11.0, respectively. 
and $27.9,27.0$, and $25.4^{\circ} \mathrm{C}$ for western wheatgrass for the 50,100 , and $150 \%$ water treatments, respectively. Canopy temperatures for the 1990 study were significantly higher for the $50 \%$ than the $100 \%$ water treatment and the $100 \%$ was significantly higher than the $150 \%$ water treatment (Table 1). Higher canopy temperatures are an indication of greater water stress, thus the observed increases in canopy temperature with decreasing amounts of applied water indicate water treatments were effective in producing differing levels of plant stress for both crested and western wheatgrass.

\section{Proline}

Proline concentration in both crested wheatgrass and western wheatgrass was higher on most sample dates as water level decreased from 150 to $50 \%$ rainfall (Fig. 3). The water treatment $x$ Haun stage interaction was significant for both species. Proline decreased as crested wheatgrass developed from Haun 4.1 to 10.0, but in western wheatgrass proline decreased until Haun stage 6.4 , and then increased from Haun stages 6.4 to 11.0. This differential species response for proline accumulation during the later stages of plant development may be related to differences in rate of growth during drought.
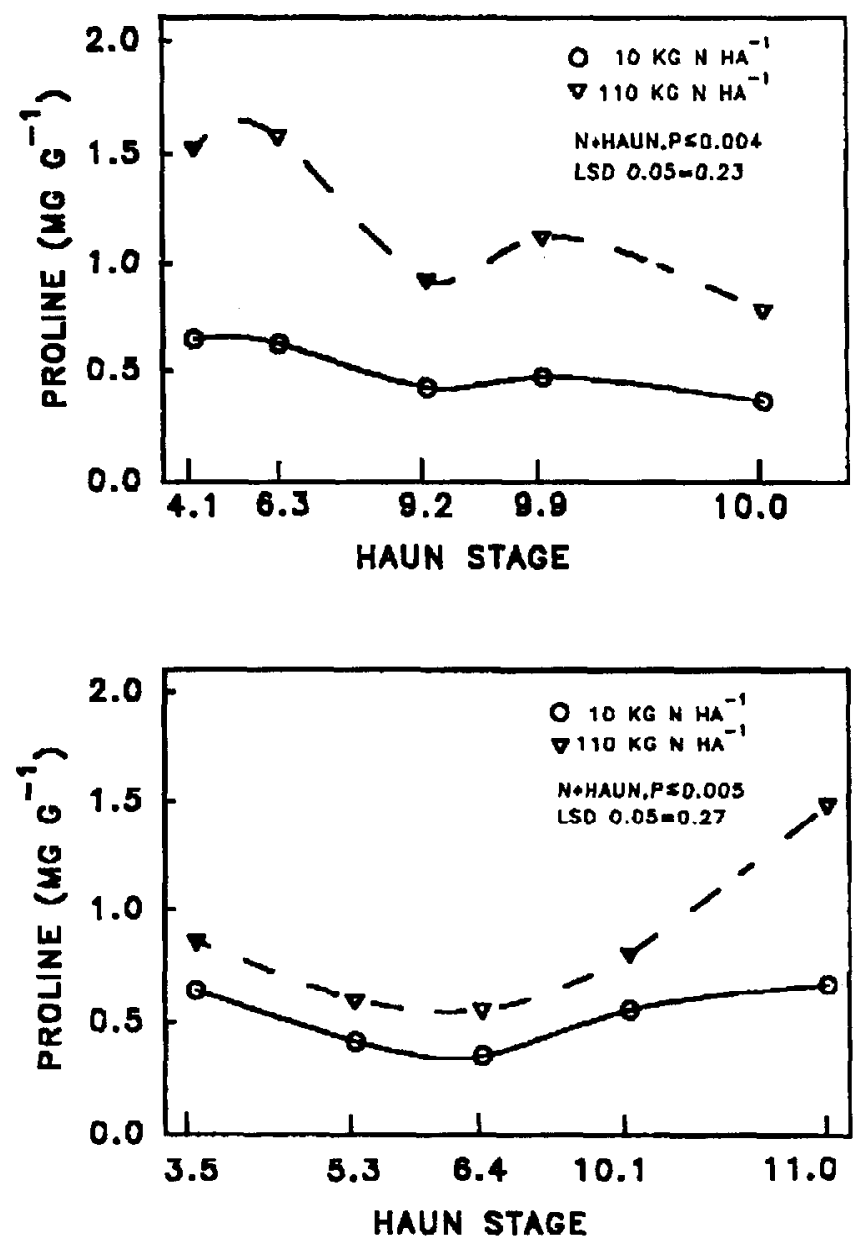

Fig. 4. Proline concentration during development of crested wheatgrass (top) and western wheatgrass (bottom) grown at 10 and $110 \mathrm{~kg} \mathrm{~N} \mathrm{ha.1}$. The date that corresponded to each Haun stage is given in caption of Figure 3.
Fertilizer nitrogen applied at $110 \mathrm{vs} 10 \mathrm{~kg} \mathrm{~N}^{-1}$ increased proline concentration more in crested than western wheatgrass (Fig. 4). Seasonal proline accumulation pattern differed for each species and $\mathrm{N}$ rate. In crested wheatgrass proline concentration decreased for both $\mathrm{N}$ rates from Haun 4.1 to 10.0, but the decrease was greater for the $110 \mathrm{~kg} \mathrm{~N}^{-1}$ rate. Proline concentration in western wheatgrass decreased from Haun stage 3.5 to 6.4 followed by an increase from Haun 6.4 to 11.0 .

A significant water treatment $x$ fertilizer $\mathrm{N}$ interaction was present for both species (Fig. 5). Proline concentration was greater for the 110 compared to the $10 \mathrm{~kg} \mathrm{~N} \mathrm{ha}^{-1}$ rate for all water treatments, except at the $150 \%$ water treatment for western wheatgrass. Proline concentration trended lower for both $\mathrm{N}$ fertilizer rates as water levels increased from 50 to the $150 \%$ water treatment. The combination of high rate of fertilizer $\mathrm{N}\left(110 \mathrm{~kg} \mathrm{~N} \mathrm{ha}^{-1}\right)$ and low levels of water $(50 \%$ rainfall) produced significantly higher proline concentration in both species.

\section{Carbohydrate}

Carbohydrate content decreased rapidly during vegetative development followed by a rapid increase during final stages of heading and
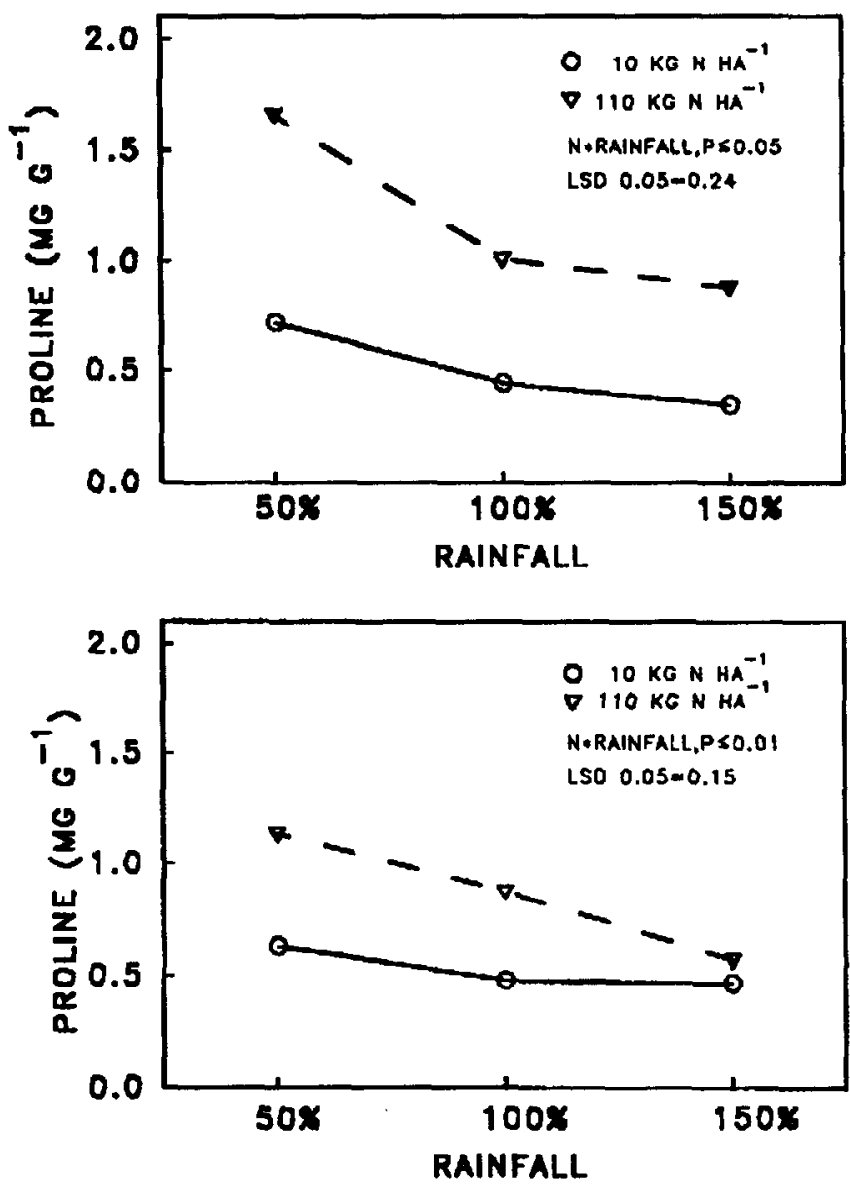

Fig. 5. Proline concentration during development of crested wheatgrass (top) and western wheatgrass (bottom) grown at 50, 100, and $150 \%$ rainfall and 10 and $110 \mathrm{~kg} \mathrm{~N} \mathrm{ha.-}$ 

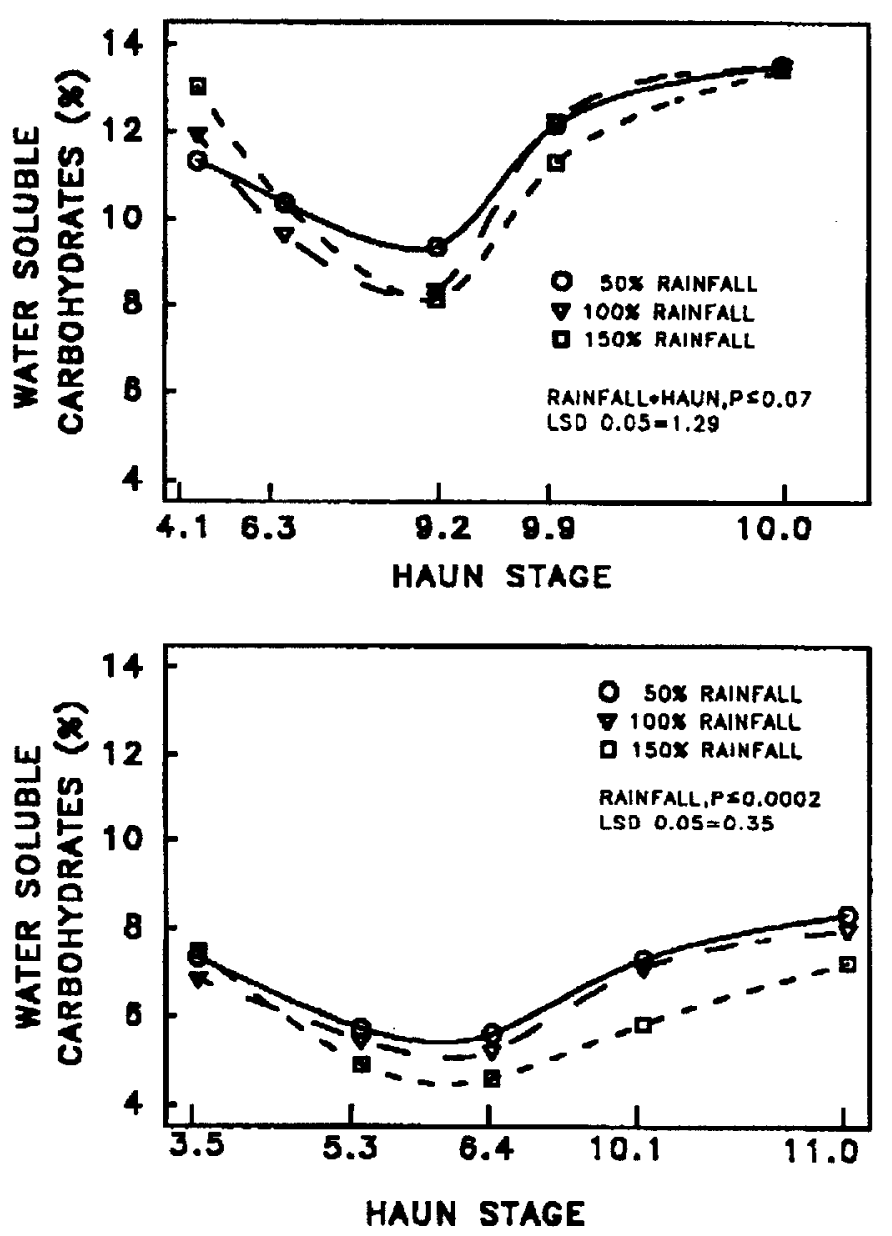

Fig. 6. Water soluble carbohydrates (WSC) during development of crested wheatgrass (top) and western wheatgrass (bottom) grown at 50, 100 , and $150 \%$ rainfall. The date that corresponded to each Haun stage is given in caption of Figure 3.

seed formation (Fig. 6). The Haun stage $x$ rainfall interaction was significant for crested wheatgrass, but nonsignificant for western wheatgrass. Carbohydrate concentration increased significantly as water level decreased from 150 to $50 \%$ for western wheatgrass, but not for crested wheatgrass. Carbohydrate concentration in western wheatgrass averaged over sample dates was $6.9,6.5$, and $6.0 \%$ for the 50,100 , and $150 \%$ treatments, respectively. Carbohydrate concentration averaged across all treatments was $11.2 \%$ for crested and $6.4 \%$ for western wheatgrass.

The fertilizer $\mathbf{N} \times$ Haun stage interaction was significant for both species (Fig. 7). Carbohydrate content of crested wheatgrass decreased to Haun stage 9.2, which is after heading, then increased as the forage matured. In western wheatgrass carbohydrate content decreased to Haun 6.4, which is pre-heading, then increased as forage matured. Plants of both species that received $10 \mathrm{~kg} \mathrm{~N} \mathrm{ha-1}$ contained higher carbohydrate concentration on all but the last 2 sample dates compared to plants receiving $110 \mathrm{~kg} \mathrm{~N} \mathrm{ha}^{-1}$.

\section{Abscisic Acid and Proline}

Leaf abscisic acid concentration was not significantly different for either species between the 50 and $\mathbf{1 0 0 \%}$ rainfall treatments (Table 2). However, abscisic acid in both species at 50 and $100 \%$ treatments was significantly higher than at $150 \%$ rainfall. Abscisic acid was
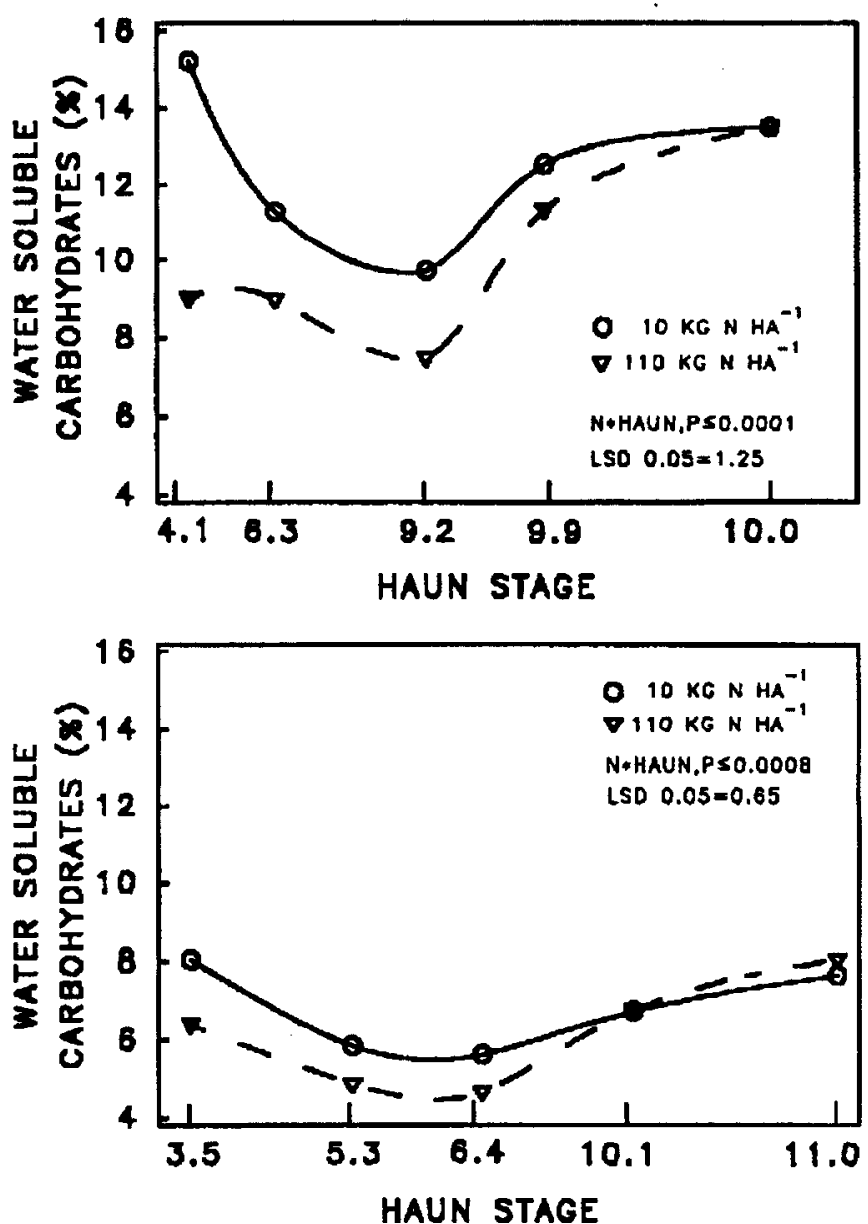

Fig. 7. Water soluble carbohydrates (WSC) during development of crested wheatgrass (top) and western wheatgrass (bottom) grown at 10 and $110 \mathrm{~kg} \mathrm{~N} \mathrm{ha}^{-1}$. The date that corresponded to each Haun stage is given in caption of Figure 3.

higher in western wheatgrass $\left(1,139 \mathrm{ng}^{-1}\right)$ than crested wheatgrass $\left(658 \mathrm{ng} \mathrm{g}^{-1}\right)$ when averaged across rainfall treatments. The trend was for higher abscisic acid at all sample datcs as water level dccreased (data not shown), but the water treatment $x$ Haun interaction was not significant. Proline concentration decreased in both species as applied water increased from $50 \%$ to $150 \%$ treatments (Table 3). Overall, concentrations of proline were higher in crested wheatgrass (1.02 $\mathrm{mg} \mathrm{g}^{-1}$ ) than western wheatgrass $\left(0.38 \mathrm{mg} \mathrm{g}^{-1}\right)$. Since the rainfall $x$ Haun stage interaction was significant for proline concentration, but not for abscisic acid concentration, main effects only are reported in Tables 2 and 3.

\section{Discussion}

Crested wheatgrass and western wheatgrass are both cool-season grasses well adapted to the semiarid Northern Great Plains. Crested wheatgrass escapes drought through senescence and dormancy during the summer months, whercas western wheatgrass reduces growth rate but remains green during drought (Frank 1988). Frank (1983) reported lower leaf water potentials at zero turgor potential for crested wheatgrass $(-2.8 \mathrm{MPa})$ than for western wheatgrass $(-2.3 \mathrm{MPa})$. Western wheatgrass also has the ability to maintain a higher leaf 
Table 2. Abscisic acid concentration in crested and western wheatgrass grown at 50,100 , or $150 \%$ of average growing season rainfall in 1990 . The Haun stage $x$ rainfall interaction was not significant $(P>0.05)$.

\begin{tabular}{lcc}
\hline \hline Rainfall & Crested Wheatgrass & Western Wheatgrass \\
\hline$\ldots \%$-.. & 851 & 1386 \\
50 & 767 & 1352 \\
100 & 355 & 679 \\
150 & 270 & 352 \\
\hline
\end{tabular}

water potential.

The rainfall $x$ Haun interaction (Fig. 3) shows an increase in proline concentration in western wheatgrass but a decrease in crested wheatgrass as the plants mature. Although crested wheatgrass contained higher average proline concentrations throughout the season, proline concentration decreased at all rainfall treatments as Haun stage increased. In western wheatgrass proline content decreased at the early Haun stages, but then increased through advancing plant maturity. The increase in proline during the later stages of plant development may condition western wheatgrass to better tolerate drought and continue slow growth. The observed increases in proline accumulation in western wheatgrass during the season, and decreases for crested wheatgrass suggest that in these species proline may not be a measure of rate of stress development, but could possibly explain why western wheatgrass remains green and continues to grow slowly during summer stress periods and crested wheatgrass becomes dormant.

Proline accumulation was significantly increased by application of $\mathbf{N}$ fertilizer. These results suggest that increased $\mathbf{N}$ elicited a response similar to that of decreasing rainfall levels. Perhaps increased growth caused by $\mathbf{N}$ created water stress, which then increased proline. The data in Figs. 3 and 4 suggest that sampling for tissue proline concentration throughout the season provides valuable information on species responses to water stress that could not be gained from only 1 or 2 sample dates.

The greater proline concentration at the higher rate of applied $\mathrm{N}$ (Fig. 5) is in concert with the suggested role of proline as a readily available pool of nitrogen during recovery of plants from water stress (Blum and Ebercan 1976; Itai and Paleg 1982). The role of proline accumulation in plants has also been related to many aspects of drought tolerance. For example, Barnett and Naylor (1966) and Sivaramakrishnan et al. (1988) suggested the role of proline accumulation was as a storage mechanism for nitrogen and carbon, whereas Dingkuhn et al. (1991) suggested that proline is merely an indicator of rate of stress development. Voetberg and Sharp (1991) reported that osmotic adjustment due to increased proline accumulation played an important role in the maintenance of root elongation in maize at low water potentials. Osmotic adjustment is also important for drought tolerance in cool season grasses (Frank 1983) and proline accumulation may enhance osmotic adjustment.

The seasonal pattern of carbohydrate concentration was typical of cool-season grasses (Daer and Willard 1981). High carbohydrate concentration in western wheatgrass was in concert with proline concentration with the $50 \%$ rainfall treatment having higher levels than $100 \%$ which trended higher than the $150 \%$. This may be important if proline synthesis protects carbon metabolism through enhanced osmotic adjustment.
Table 3. Proline concentration in crested and western wheatgrass grown at 50, 100, or $150 \%$ of average growing season rainfall in 1990. The Haun stage $x$ rainfall interaction was significant $(P<0.05)$.

\begin{tabular}{lcc}
\hline \hline Rainfall & Crested Wheatgrass & Western Wheatgrass \\
\hline$\ldots \%$... & 2.09 & 0.63 \\
50 & 0.70 & 0.36 \\
100 & 0.26 & 0.16 \\
150 & 0.33 & 0.08 \\
LSD (0.05) Rainfall & & \\
\hline
\end{tabular}

Carbohydrate concentrations were consistently greater in crested wheatgrass compared to western wheatgrass at all treatment levels and development stages. These high water soluble carbohydrate concentrations serve as a source of energy for plants as they are subjected to stress levels. High abscisic acid and proline concentrations may be equally important constituents in determining plant response to water stress and drought tolerance.

The presence of nearly 1.7 times higher abscisic acid concentration in western than in crested wheatgrass (Table 2) may trigger physiological mechanisms that contribute to the greater stress tolerance in western wheatgrass than crested wheatgrass. Proline accumulation induced by abscisic acid has been shown to occur in barley (Rajagopal and Anderson 1978) and maize (Pesci 1987). Data in Tables 2 and 3 show an increase in both abscisic acid and proline for both species as water stress (less rainfall) increases. This relationship between abscisic acid and proline does not suggest that abscisic acid induces proline synthesis, but since both constituents increase with stress more than a casual relationship is possible.

These results showing that the physiological response of western wheatgrass to water stress differs from that of crested wheatgrass should be useful in understanding responses of both species during drought. Understanding species differences is important for good grassland management. The seasonal changes in proline concentration suggests that sampling over time may be necessary in evaluating proline concentrations in germplasm.

\section{Literature Cited}

Aspinall, D., and L. D. Paleg. 1981. Proline accumulation. Physiological aspects, p. 206-240. In: L. G. Paleg and D. Aspinall (eds.), The physiology and biochemistry of drought resistance in plants. Academic Press, Sydney.

Barnett, N. M., and A. W. Naylor. 1966. Amino acid and protein metabolism in bermuda grass during water stress. Plant Physiol. 41:1222-1230.

Bates, L. S., R. P. Waldren, and I. D. Teare. 1973. Rapid determination of free proline for water stress studies. Plant Soil 39:205-207.

Bittman, S., and G. M. Simpson. 1989. Drought effects on water relations of three cultivated grasses. Crop Sci. 29:992-999.

Blum, A., and A. Ebercon. 1976. Genotypic responses in Sorghum to drought stress. III. Free proline accumulation and drought resistance. Crop Sci. 16:428-431.

Bokhari, U. G., and J. D. Trent. 1985. Proline concentrations in water stressed grasses. J. Range Manage. 38:37-38.

Busso, C. A., J. H. Richards, and N. J. Chatterton. 1990. Nonstructural carbohydrates and spring regrowth of two cool-season grasses: Interaction of drought and clipping. J. Range Manage. 43:336-343.

Buwai, M., and M. J. Trlica. 1977. Defoliation effects on root weights and total nonstructural carbohydrates of blue grama and western wheatgrass. Crop Sci. 17:15-17.

Daer, T., and E. E. Willard. 1981. Total nonstructural carbohydrate trends 
in bluebunch wheatgrass related to growth and phenology. J. Range Manage. 34:377-379.

Dingkuhn, M., R. T. Cruz, J. C. O'Toole, N. C. Turner, and K. Doerffing. 1991. Response of seven diverse rice cultivars to water deficits. III Accumulation of abscisic acid and proline in relation to leaf waterpotential and osmotic adjustment. Field Crop Research 27:103-117.

Ford, C. W., and J. R. Wilson.1981. Changes in levels of solutes during osmotic adjustment to water stress in leaves of four tropical pasture species. Aust. J. Plant Physiol. 8:77-91.

Frank, A. B. 1983. Plant water relationships of crested, pubescent, slender, and western wheatgrasses, p. 399-401. In: J. A. Smith and V. W. Hays, (eds.) Proc. XII Int. Grass. Congr. Lexington, Kentucky, 15-24 June 1983. Westview Press, Boulder, Colo.

Frank, A. B. 1988. Physiological and morphological responses of forage grasses. p. 16-20. In: R. S. White and R. E. Short, (eds.) Proc. Fort Keogh research symposium, achieving efficient use of rangeland resources. Montana Agr. Exp. Sta., Bozeman, Mont.

Haferkamp, M. R., P. O. Currie, J. D. Volesky, and B. W. Knapp. 1992. Mortality of crested wheatgrass and Russian wildrye during drought. J. Range Manage. 45:355-357.

Haun, J. R. 1973. Visual quantification of wheat development. Agron. J. 65:116-119.

llahi, I., and K. Doerffling. 1982. Changes in abscisic acid and proline levels in maize varieties of different drought resistance. Physiol. Plant. , 55:129135.

Itai, C., and L. C. Paleg. 1982. Response of water-stressed Hordeum distichum L. and Cucumis sativus to proline and betaine. Plant Sci. Let. 25:329-335.

Jones, R. J., and C. J. Nelson. 1979. Respiration and concentration of water soluble carbohydrates in plant parts of contrasting tall fescue genotypes. Crop Sci. 19:367-372.
Pesci, P. 1987. ABA-induced proline accumulation in barley leaf segments:dependence on protein synthesis. Physiol. Plant. 71:287-291.

Quarrie, S. A. 1980. Genotypic differences in leaf water potential, abscisic acid and proline concentration in spring wheat during drought stress. Ann. Bot. 46:383-394.

Rajagopal, V., and A. S. Andersen. 1978. Does abscisic acid influence proline accumulation in stressed leaves? Planta. 143:85-88.

SAS Institute, Inc. 1990. SAS/STAT User's Guide, Version 6, Fourth Edition, Vol. 2, SAS Inst., Cary, N. C. p. 886.

Sivaramakrishnan, S., V. Z. Patell, D. J. Flower, and J. M. Peacock. 1988. Proline accumulation and nitrate reductase activity in contrasting sorghum lines during mid-season drought stress. Physiol. Plant. 74:418-426.

Smith, D. 1969. Removing and analyzing total nonstructural carbohydrates from plant tissues. Wisconsin Agr. Exp. Sta.. Res. Bull. 41. Madison, Wisc.

Stewart, C. R., and A. D. Hanson. 1980. Proline accumulation as a metabolic response to water stress, p. 173-189. In: N. C. Turner and P. J. Kramer (eds.). Adoption of plants to water and high temperature stress. Wiley and Sons, Inc., N. Y.

Tadmore, N. H., M. Evenari, and L. Shanan. 1970. Runoff farming in the desert. IV. Survival and yields of perennial range plots. Agron. J. 62:695699.

Trlica, M. J., and C. W. Cook. 1972. Carbohydrate reserves of crested wheatgrass and Russian wildrye as influenced by development and defoliation. J. Range Manage. 25:430-435.

Voetberg, G. S., and R. E. Sharp. 1991. Growth of maize primary root at low water potentials. III. Role of increased proline deposition in osmotic adjustment. Plant Physiol. 96:1125-1130. 